\title{
Polya Steps for Analyzing Errors in Mathematical Problem Solving
}

\author{
Suharti 1, Fitriani Nur 2, Bahrul Alim 3 \\ DOI: $10.35445 /$ alishlah.v13i1. 570
}

\begin{tabular}{ll}
\hline Article Info & Abstract \\
\hline Keywords: & This research aims to ascertain the proportion of mistakes made by students \\
Error Analysis & while solving comparative and social arithmetic problems. This study falls \\
Math Problems & under the category of qualitative descriptive research. Twenty-six students from \\
class VII. 6 were used as study participants. Data were gathered via interviews \\
and administering exams. The analytical framework was derived from Polya's \\
classification of errors. The findings of this research show that type of mistake. \\
According to this research, mistakes in evaluating responses (fourth phase) are \\
more prevalent than other types of errors. The fourth phase received a score of \\
43,8\%, whereas the first phase received a score of 34,9\%, the second phase \\
received a score of $35,4 \%$, and the third phase received a score of $36,5 \%$. The \\
mistakes in the first and second phases are indicative of fundamental and \\
conceptual problems. The third level demonstrates mistakes in the processes \\
and algorithms, followed by faults in confirming the solutions. The consequence \\
of this study is the identification of pictures of mistakes made while answering \\
comparison questions and social arithmetic, allowing for the development of \\
more effective learning methods for future learning.
\end{tabular}

Kata kunci: Analisis Kesalahan Penyelesaian Permasalahan Permasalahan Matematika

\begin{abstract}
Abstrak
Penelitian ini bertujuan untuk mengetahui persentase kesalahan yang dilakukan oleh peserta didik saat mengerjakan soal perbandingan dan aritmatika sosial. Penelitian ini termasuk dalam kelompok penelitian deskriptif kualitatif. Subjek penelitian ialah paserta didik dari kelas VII.6 SMPN 1 Watansoppeng dengan jumlah 26 orang. Data dikumpulkan dengan cara wawancara dan pemberian tes. Kerangka analisis diadaptasi dari kategori kesalahan Polya. Hasil dari penelitian ini menunjukkan kesalahan dalam meninjau ulang jawaban (fase keempat) paling dominan dari kesalahan yang lain. Fase keempat mendapat skor $43,8 \%$ sedangkan fase pertama $34,9 \%$, kedua $35,4 \%$, dan ketiga $36,5 \%$. Kesalahan dalam tahap pertama dan kedua menunjukkan kesalahan prinsip dan konsep, tahap ketiga menunjukkan kesalahan langkah dan algoritma, lalu tahap keempat menunjukkan kesalahan penegasan jawaban. Implikasi dari temuan ini yaitu ditemukannya gambaran-gambaran kesalahan pada saat menyelesaikan soal perbandingan dan aritmatika sosial sehingga untuk pembelajaran selanjutnya dapat dilakukan strategi-strategi pembelajaran yang lebih baik.
\end{abstract}

\footnotetext{
${ }^{1}$ Universitas Islam Negeri Alauddin Makassar, Makassar, Indonesia Email: suharti.harti@uin-alauddin.ac.id

${ }^{2}$ Universitas Islam Negeri Alauddin Makassar, Makassar, Indonesia

Email: fitrianinur@uin-alauddin.ac.id

3 Universitas Islam Negeri Alauddin Makassar, Makassar, Indonesia

Email:bahrulalim941@gmail.com
} 
PENDAHULUAN

Pendidikan ialah kegiatan yang menerapkan beberapa metode tertentu agar individu mendapatkan pemahaman, ilmu, dan cara berperilaku baik sesuai kebutuhan (Ichsan, 2016). Pendidikan bukan hanya sebatas pengajaran, namun juga proses pengalihan ilmu, nilai, dan karakter dalam segala aspek. Pendidikan dibutuhkan untuk mendapatkan keseimbangan serta kesempurnaan bagi setiap individu (Nurkholis, 2013). Karena pendidikan, individu mampu memantaskan bakat dirinya sebagai bekal bereksistensi dalam dunia yang pastinya bermanfaat bagi masyarakat dan dirinya (Nengrum et al., 2021). Oleh karena itu penyelenggaraan Pendidikan perlu dilakukan dengan sangat terencana, sehingga segala hal yang menjadi factor saat proses Pendidikan harus diketahui terlebih dahulu (Asyafiq, 2016).

Matematika menjadi pondasi bagi ilmu lain yang digunakan dalam semua hal (Wati \& Sujadi, 2017). Matematika juga disebut king of knowledge karena menjadi dasar dalam berpikir yang logis, kritis, terstruktur, serta efektif dan efisian saat memecahkan permasalahan (Dirgantoro, 2018) Matematika bukan sekedar berhitung dan menghafalkan rumus, tapi juga membahas mengenai konsep dan struktur dari sebuah materi (Wati \& Sujadi, 2017). Matematika yang menjadi pondasi dari ilmu pengetahuan membuat ketidaktertarikan bagi sebagian besar peserta didik karena rumit dan banyaknya hafalan rumus serta ketelitian tinggi yang diperlukan (Sitorus \& Sutirna, 2021). Keadaan ini menimbulkan kendala yang bisa mengganggu keterlaksanaan pembelajaran. Kendala ini condong bersifat merugikan karena bisa memperlambat individu mengerjakan suatu hal (Effendi dalam Sitorus \& Sutirna, 2021).

Tujuan dari pembelajaran matematika dikatakan terpenuhi jika para siswa mampu memahami dan mengaplikasikan pemahamannya ketika menyelesaikan suatu persoalan baik yang menyangkut matematika ataupun pelajaran lain. Oleh sebab itu setidaknya para siswa perlu mempunyai kemampuan memahami konsep (Fajar et al., 2018). Agar hal ini bisa terpenuhi, maka peran guru sangatlah penting dalam menciptakan situasi belajar (Wibowo \& Farnisa, 2018) yang bisa mengantar para siswa mencapai kompetensi tertentu. Kompetensi tertentu tersebut bisa dicapai apabila pihak guru mengetahui dan melakukan pengidentifikasian terhadap apa yang menjadi kendala peserta didik pada materi yang diberikan (Haryadi \& Nurmaningsih, 2019).

Adanya kesulitan yang dihadapi para siswa memungkinkan terjadinya kesalahan dalam memecahkan suatu permasalahan matematika. Kesalahan ialah bentuk kekeliruan dari jawaban sesungguhnya yang sifatnya sistematis (Ardiawan, 2015). Kesalahan peserta didik sangat perlu dianalisis agar pembejaran mendapatkan saran untuk perbaikan dan bisa menjadi referensi dalam meningkatkan keefektifan pembelajaran matematika selanjutnya (Fitra, 2020). Pemecahan masalah termasuk salah satu kemampuan wajib dipahami oleh peserta didik (Sitorus \& Sutirna, 2021). Pemecahan masalah ialah suatu upaya dalam mencari solusi dari tujuan yang tidak mudah untuk segera dicapai (Hendriana et al., 2017).

Kesalahan saat memecahkan masalah sudah sering terjadi selama belajar matematika. Peserta didik banyak mendapat kendala disebabkan pemecahan masalah di dalam pembelajaran matematika merupakan suatu keterampilan yang kompleks. Ada peserta didik yang mengetahui cara menjawab soal namun teledor dalam hal perhitungan (kurang teliti) (Sulistyaningsih \& Rakhmawati, 2017). Ada juga yang paham akan konsep terkait materi yang diberikan, namun salah menerapkan rumus saat mengerjakan sebuah soal (Farida, 2015). Bahkan ada peserta didik yang belum mengerti dengan konsep terkait materi yang diberikan namun mampu menghasilkan jawaban benar karena mengandalkan unsur logika dari dirinya sendiri (Wati \& Sujadi, 2017). Kesalahan-kesalahan seperti ini menjadi gambaran sejauh mana penguasaan peserta didik terhadap suatu materi (Siswandi et al., 2016).

Dari data dalam hasil tes PISA di tahun 2015, Indonesia menduduki peringkat ke-64 dari total 72 negara, ini menunjukkan bahwa penguasaan peserta didik di Indonesia dalam matematika secara keseluruhan masih rendah di mana salah satu penyebabnya karena kesalahan dalam memecahkan masalah (Sitorus \& Sutirna, 2021). Oleh sebab itu kesalahan-kesalahan dalam belajar matematika 
harus segera dituntaskan. Berdasarkan penelitian yang dilakukan Azhar \& Senjayawati (2021) kesalahan peserta didik mayoritas ada dalam indikator perhitungan khususnya dalam menghitung jarak garis dengan garis serta besaran sudut dalam materi geometri ruang. Sementara Aulia \& Kartini (2021) dalam penelitiannya mendapatkan bahwa kesalahan peserta didik lebih kepada kesalahan konsep dan prosedural pada materi himpunan. Lalu penelitian yang dilakukan Dewi \& Kartini (2021) mengemukakan bahwa kesalahan yang dialami peserta didik ialah dalam hal membaca soal, memahami, keterampilan proses karena keliru melakukan prosedur penyelesaian, serta penulisan notasi. Oleh sebab itu dilaksanakan penelitian ini agar dapat diketahui persentase kesalahan yang dilakukan peserta didik dalam menyelesaikan soal perbandingan dan aritmatika sosial.

\section{METODE}

Penelitian ini menggunakan penelitian deskriptif yang mempunyai target dalam menentukan persentase kesalahan para peserta didik saat menyelesaikan soal perbandingan dan aritmatika sosial. Penelitian kualitatif diartikan sebagai jenis pengamatan yang bermaksud untuk mengerti dengan suatu keadaan yang dialami oleh subjek dari penelitian dengan menjabarkan secara detail menggunakan kalimat dengan tetap memanfaatkan metode alamiah (Moleong, 2018).

Penelitian ini dilaksanakan saat semester genap dengan subjek penelitian yaitu peserta didik kelas VII SMP Negeri 1 Watansoppeng, karena penelitian sederhana ini dilaksanakan saat kondisi pandemi covid 19 maka peneliti hanya fokus pada satu kelas saja. Subjek penelitian ini juga mewakili populasi penelitian, sementara sampel yang dipilih ialah kelas VII.6 dengan jumlah 26 orang agar dapat dengan mudah dideteksi kelompok belajarnya karena kondisi masih dalam suasana berajar daring. Data dikumpulkan melalui tes juga wawancara. Tes ini diselenggarakan dengan bantuan aplikasi WhatsApp di mana para siswa mengerjakan soal yang dikirim, sementara wawancara dilakukan dengan chat melalui WhatsApp. Mekanisme ini dilaksanakan sebab adanya pandemi Covid-19 yang belum memungkinkan untuk bertatap muka. Indikator kemampuan peserta didik memecahkan masalah berpatokan pada tahapan polya yakni: 1) Pemahaman, tujuannya untuk mengetahui pemahaman subjek penelitian perihal yang ditanyakan dalam soal, 2) Perencanaan penyelesaian, tujuannya untuk mengidentifikasi langkah yang digunakan dalam menyelesaikan permasalahan, 3) Pelaksanaan, dan 4) Peninjauan Kembali, tujuannya untuk memeriksa ulang kebenaran dari solusi yang didapatkan (Sitorus \& Sutirna, 2021).

Persentase tiap kesalahan dianalisis dengan rumus:

\section{Keterangan:}

$$
P_{i}=\frac{e_{i}}{N \times m_{i}} \times 100
$$

$P_{i} \quad$ : Persentase kesalahan dari soal ke-i $=1,2,3, \ldots$

$e_{i} \quad:$ Total skor kesalahan soal ke-i

N : Jumlah siswa

$m_{i} \quad$ : Skor kesalahan maksimum soal ke-i (Wati \& Sujadi, 2017)

\section{HASIL PENELITIAN DAN PEMBAHASAN}

\section{Kesalahan Saat Memahami Permasalahan}

Dalam soal pertama didapatkan persentase 7 peserta didik dari $26=26,9 \%$ yang tidak mengungkapkan apa yang mereka ketahui, 18 peserta didik dari 26=69,2\% yang tidak mengungkapkan mengenai hal yang mereka pertanyakan, serta 3 peserta didik dari $26=11,5 \%$ yang tidak mengungkapkan mengenai hal yang mereka pertanyakan dan apa yang mereka ketahui. Dalam soal kedua, 21 peserta didik dari $26=75 \%$ yang tidak mengungkapkan apa yang mereka ketahui, 4 peserta didik dari $26=15,4 \%$ yang tidak mengungkapkam megenai hal yang mereka pertanyakan, serta 3 peserta didik dari $26=11,5 \%$ yang tidak mengungkapkan dua jenis kesalahan yaitu hal yang dipertanyakan dan yang mereka ketahui. Dalam soal ketiga 9 peserta didik dari $26=34,6 \%$ yang tidak 
Al- Ishlah: Jurnal Pendidikan, June 2021, 13 (1), Pages 741-748

Suharti, Fitriani Nur, Bahrul Alim

mengungkapkan apa yang mereka ketahui, 10 peserta didik dari $26=38,5 \%$ yang tidak mengungkapkan mengenai hal yang mereka pertanyakan, serta 9 peserta didik dari $26=34,6 \%$ yang tidak mengungkapkan keduanya mengenai apa yang mereka ketahui dan tanyakan. Dalam soal keempat, 13 peserta didik dari $26=50 \%$ tidak mengungkapkan mengenai apa yang mereka ketahui, 8 peserta didik dari $26=30,8 \%$ tidak mengungkapkan tentang apa yang mereka pertanyakan, serta 5 peserta didik dari $26=19,2 \%$ tidak mengukapkan keduanya tentang apa yang mereka pertanyakan dan ketahui. Dan pada soal kelima terdapat 10 peserta didik dari $26=38,5 \%$ tidak mengungkapkan mengenai apa yang merek ketahui, 12 peserta didik dari $26=46,1 \%$ tidak mengungkapkan mengenai hal apa yang mereka pertanyakan, serta 4 peserta didik dari $26=15,4 \%$ tidak mengungkapkan hal yang mereka pertanyakan dan apa yang mereka ketahui.

Lenchner (1983) mengatakan sebelum peserta didik menggores pensilnya di kertas untuk menyelesaikan permasalahan, berikanlah ia dorongan agar berpikir mengenai masalah yang ia hadapi. Biarkan peserta didik bertanya kepada pendidik selama pertanyaan tersebut mengenai masalah yang akan diselesaikan. Dalam keadaan seperti ini, pendidik harus menahan seluruh pertanyaan yang berkaitan dengan proses pemecahan masalah. Apabila peserta didik tidak mempunyai pertanyaan. Pendidik harus mengajukan pertanyaan, pertanyaan tersebut dapat mendorong munculnya pertanyaan dari peserta didik. Lenchner mengungkapkan bahwa kesulitan peserta didik dalam memahami permasalahan berkaitan dengan bahasa dalam masalah. Apabila pendidik berpikir bahwa Bahasa merupakan tolak ukur pemahaman mereka, berikanlah pertanyaan yang memicu jawaban peserta didik dapat memberikan petunjuk letak atau sumber kesulitan peserta didik. Nanti kita akan mendapati metode yang tepat dalam bertanya sehingga peserta didik dapat mengungkapkan permasalahan yang dialaminya menggunakan Bahasa dan kata-kata mereka sendiri. Langkah yang diterapkan yaitu pengenalan kosa kata pada permasalahan yang kurang dipahami dan berarti ganda dalam permasalahan.

Siswa yang membuat kesalahan konsep berakibat pada ketidakmampuan dalam menuntaskan permasalahan di tahap selanjutnya. Dalam tahap ini peserta didik melakukan kesalahan dalam menafsirkan permasalahan soal pertama. Sehingga peserta didik belum dapat dikategorikan sebagai melakukan kesalahan memahami permasalahan. Hal itu terjadi karena indikator kesalahan belum terpenuhi (Widodo, 2013).

Berikut hasil wawancara yang dilakukan kepada responden untuk mengetahuai kenapa peserta didik melakukan kesalahan, sebagai berikut:

$P \quad$ : "Coba perhatikan jawaban pada soal pertama, kenapa tidak melengkapi mengenai hal yang diketahui dan ditanyakan? "

$R \quad$ : "Biasanya kak kelau mengerjakan soal begitu, saya tidak pernah menuliskan apa yang diketahui dan ditanyan dilembar jawaban, langsung saja jawabannya"

$P \quad$ : "Kenapa bisa seperti itu dek?"

$R \quad: \quad$ "Sudah terbiasa sejak dulu kak, kalau mengerjakan soal uraian langsung menulis jawabannya saja."

$P \quad$ : "Itu jangan dibiasakan dek karena dalam mengerjakan soal metematika itu harus menuliskan dengan lengkap apa yang diketahui dan ditanyakan agar kita mudah dalam mengerjakan soal."

$R \quad$ : "Iya kak, tapi saat pengerjaan soal saya takut kehabisan waktu kalau harus menuliskan apa yang diketahui dan yang ditanyakan."

$P \quad$ : "Memang kemarin waktunya tidak cukup yah?"

$R \quad$ : "Cukup kak."

$P \quad$ : "Ok, lain kali perlu dituliskan yah prosedur nya secara lengkap, jangan terbiasa langsung menliskan jawaban."

$R \quad$ : "Iya kak."

Dari wawancara tersebut, dapat diketahui peserta didik yang melakukan kesalahan karena tidak melengkapi apa yang diketahui dan ditanyakan dalam menyelesaikan soal akan tetapi ia dapat menangani tahapan selanjutnya, bukan berarti peserta didik tersebut tidak memahami masalah, tetapi mereka terbiasa dalam menyelesaikan soal uraian tanpa melengkapi apa yang diketahui dan 
ditanyakan. Alasan lain yang disampaikan peserta didik karena takut kehabisan waktu. Berikut hasil pekerjaan dari peserta yang tidak melengkapi mengenai hal yang diketahui dan dipertanyakan pada soal:

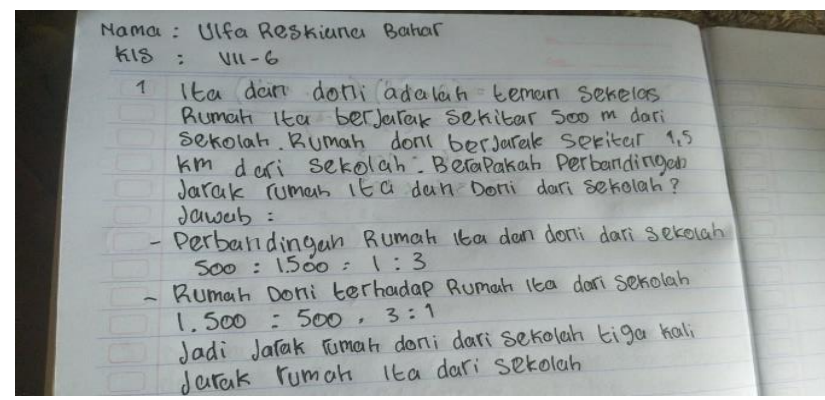

Gambar 1. Hasil pekerjaan peserta didik

\section{Kesalahan Membuat Rencana}

Dalam soal pertama, diperoleh bahwa 15 peserta didik dari $26=57,7 \%$ membuat kesalahan konsep dan 11 peserta didik dari $26=42,3 \%$ membuat kesalahan prinsip. Pada soal kedua, terdapat 8 peserta didik dari 26=30,8\% membuat kesalahan konsep dan 12 peserta didik dari 26=46,1\% membuat kesalahan prinsip. Pada soal ketiga, diperoleh 14 peserta didik dari $26=53,8 \%$ membuat kesalahan konsep dan 7 peserta didik dari $26=26,9 \%$ membuat kesalahan prinsip. Soal keempat, diperoleh 3 peserta didik dari 26=11,5\% membuat kesalahan konsep dan 6 peserta didik dari $26=23 \%$ membuat kesalahan prinsip. Dan soal kelima terdapat 9 peserta didik dari $26=34,6 \%$ membuat kesalahan konsep dan 7 peserta didik dari $26=26,9 \%$ membuat kesalahan prinsip.

Kesalahan yang sering terjadi dalam membuat rencana karena peserta didik tidak memahami strategi penyelesaian secara tepat. Peserta didik tidak dapat menyusun strategi disebabkan karena tidak terbiasa dan langsung menyelesaikan soal tanpa menyusun strateginya lebih awal menggunakan kalimat. Peserta didik yang menuliskan rencananya, langkah yang ia tuliskan tidak sesuai dengan permasalahan dan tidak berkaitan. Sedangkan kesalahan dalam membuat rencana karena kemampuan pengetahuan operasi matematika yang minim, peserta didik kesulitan mengolah data pada rumus yang telah dituliskan, serta kurang teliti dalam melakukan perhitungan. Cara langsung juga digunakan peserta didik dalam melakukan penyelesaian soal, hal ini karena peserta didik beranggapan ia merasa tidak perlu menuliskan prosedur dalam menyelesaikan soal karena hanya membuang- buang waktu (Komarudin, 2016).

Agar dapat mengetahui mengapa peserta didik tidak dapat membuat rencana, wawancara dilakukan kepada peserta didik karena telah melakukan kesalahan dalam membuat rencana. Berikut hasil wawancara yang telah dilakukan:

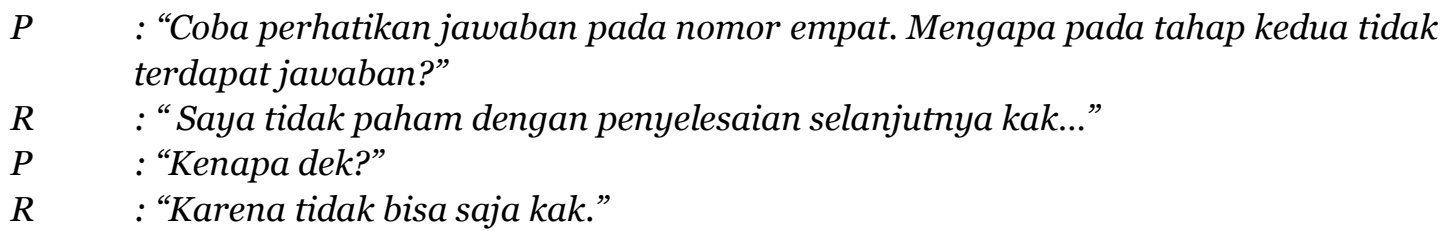

Dari proses wawancara tersebut, dipahami bahwa peserta didik yang tidak dapat membuat rencana disebabkan minimnya pengetahuan rumus yang akan digunakan dalam penyelesaian masalah tersebut. Peserta didik hanya menuntaskan permasalahan di tahap pertama (memahami permasalahan) yaitu menuliskan apa saja yang diketahui dalam soal. Hasil penelitian ini sejalan dengan hasil penelitian yang diperoleh oleh Hidayat \& Pujiastuti (2019). Berikut hasil pekerjaan dari peserta didik yang telah diwawancarai: 


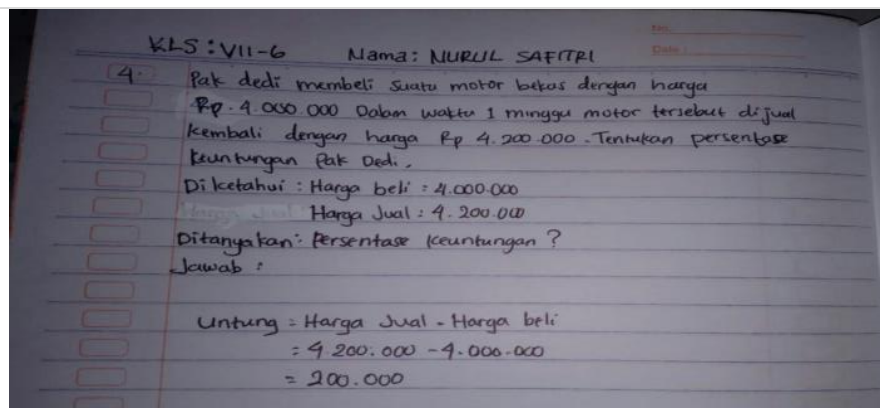

\section{Gambar 2. Hasil pekerjaan peserta didik setelah wawancara}

\section{Kesalahan Melaksanakan Rencana}

Dalam soal pertama, terdapat 16 peserta didik dari 26=61,5\% melakukan kesalahan prinsip dan 10 peserta didik dari $26=38,5 \%$ melakukan kesalahan prosedur. Dalam soal kedua, diperoleh 8 peserta didik dari $26=30,8 \%$ melakukan kesalahan prinsip dan 12 peserta didik dari $26=46,1 \%$ melakukan kesalahan prosedur. Soal ketiga, terdapat 9 peserta didik dari $26=34,6 \%$ melakukan kesalahan prinnsip dan 5 peserta didik dari $26=19,2 \%$ melakukan kesalahan prosedur. Soal keempat, diperoleh 8 peserta didik dari $26=30,8 \%$ melakukan kesalahan prinsi dan 3 peserta didik dari $26=11,5 \%$ melakukan kesalahan prosedur. Soal kelima, terdapat 15 Peserta didik dari $26=57,7 \%$ melakukan kesalahan prinsip dan 9 peserta didik dari $26=34,6 \%$ melakukan kesalahan prosedur.

Agar dapat mengetahui mengapa peserta didik melakukan kesalahan ditahap yang ketiga (melaksanakan rencana), dilakukanlah wawancara bersama responden.

$P \quad$ : "Silahkan perhatikan jawaban nomor 3, kenapa tidak menuliskan Langkah penyelesaian dengan lengkap? Tetapi langsung ke hasil akhirnya?"

$R \quad$ : "Supaya cepat kak. Karena takut kehabisan waktu juga."

$P \quad$ : "Kenapa begitu? Kan kakak beri waktu yang banyak dalam mengerjakan soal, terus kenapa variable pemisalan yang akan digunakan tidak dituliskan?”

$R \quad$ : "Iya kak, waktunya banyak, mungkin saya saja yang kurang teliti, untuk masalah variabelnyanya, saya kurang paham kak."

$P \quad$ : "Dalam mengerjakan soal harus menuliskan Langkah-langkahnya dek supaya bisa diketahui itu berasal dari mana dan akan lebih jelas juga cara pengerjaannya, tidak boleh langsung hasil saja, terus harus ada pemisalan variable yang akan dipakai dalam merumuskan model matematikanya."

$R \quad$ : "Iya kak, akan saya perbaiki cara kerja saya."

Dari hasil wawancara tersebut, hal yang menyebabkan kesulitan peserta didik yaitu ia tidak biasa menuliskan rencana yang ia ingin dipakai dalam melakukan penyelesaian soal, seperti halnya tidak menuliskan pemisalan untuk membuat pemodelan matematika, tidak menuliskan langkah atau proses memperoleh jawaban dari soal. Hasil penelitian tersebut sejalan dengan hasil penelitian yang di peroleh oleh Widyawati et al. (2018). Hal tersebut dapat dilihat dari wawancara yang telah dilakukan bersama peserta didik di atas.

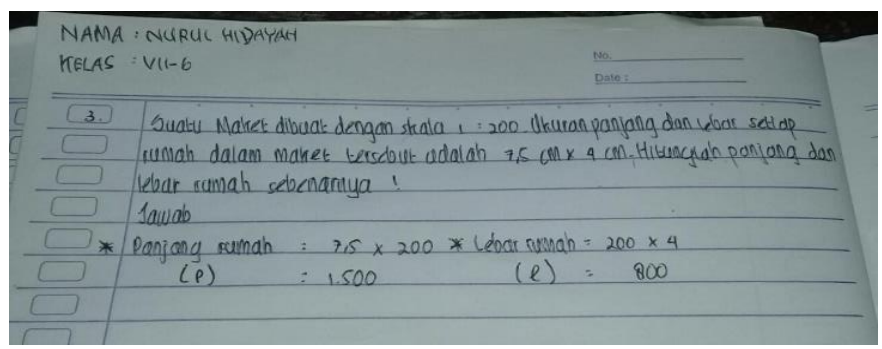

Gambar 3. Kesalahan pemodelan matematika

\section{Kesalahan Memeriksa Kembali Jawaban}

Dalam tahap ini, peserta didik membuat kesalahan saat memeriksa atau mengecek kembali jawaban dari soal yang telah dikerjakan, pada soal yang pertama, terdapat 17 peserta didik dari $26=65,4 \%$. Dalam soal kedua, terdapat 12 peserta didik dari $26=46,1 \%$. Pada soal ketiga, terdapat 13 
peserta didik dari $26=50 \%$, pada soal keempat terdapat 7 peserta didik dari $26=26,9 \%$. Dalam soal kelima, terdapat 8 peserta didik dari $26=30,8 \%$.

Dalam tahapan ini hampir seluruh peserta didik tidak memeriksa jawabannya kembali. Saat hendak ditanya, ia menjawab tidak mengetahui apa yang harus dilakukan dalam tahap ini ia memiliki anggapan bahwa tidak perlu mengecek kembali jawaban yang telah ia kerjakan karena yakin jawaban yang telah ia tulis sudah benar. Akibatnya, peserta didik melakukan kesalahan pencapaian akhir, kesalahan dalam prosedur dan konsep, hal yang serupa ditemukan dalam penelitian Ramadhan et al. (2021).

\section{SIMPULAN}

Kesalahan peserta didik bisa dijadikan sebagai pedoman agar dapat mengetahui tingkat penguasaan dan pemahaman materi peserta didik yang telah diberikan. Hasil dari penelitian menunjukkan persentase kesalahan peserta didik dalam penyelesaian permasalahan matematika menggunakan langkah polya pada tahap pertama adalah $34,9 \%$, pada fase kedua $35,4 \%$, pada fase ketiga $36,5 \%$, dan fase keempat $43,8 \%$.

Dari keempat fase tersebut, mulai dari kesalahan dalam pemahaman permasalahan, kesalahan dalam membuat perencanaan, kesalahan dalam pelaksanaan perencanaan, dan kesalahan dalam mengecek jawaban. Bisa kita ketahui bahwa fase yang banyak melakukan kesalahan pada kelas VII.6 SMPN 1 Watansoppeng 2020/2021 dalam melakukan penyelesaian permasalahan matematika Ulangan Tengah Semester yaitu pada fase keempat yang meninjau kembali jawaban yang telah dikerjakan. Implikasi dari temuan ini yaitu ditemukannya gambaran-gambaran kesalahan pada saat menyelesaikan soal perbandingan dan aritmatika sosial sehingga untuk pembelajaran selanjutnya dapat dilakukan strategi-strategi pembelajaran yang lebih baik.

\section{DAFTAR PUSTAKA}

Ardiawan, Y. (2015). Analisis Kesalahan Mahasiswa dalam Menyelesaikan Soal Induksi Matematika di IKIP PGRI Pontianak. Jurnal Pendidikan Informatika dan Sains, 4(1), 147-163. https://doi.org/10.31571/saintek.v4i1.13

Asyafiq, S. (2016). Berbagai Pendekatan dalam Pendidikan Nilai dan Pendidikan Kewarganegaraan. Jurnal Dimensi Pendidikan dan Pembelajran, 4(1), 29-37. https://doi.org/10.24269/dpp.v4i1.56

Aulia, J., \& Kartini. (2021). Analisis Kesalahan Siswa dalam Menyelesaikan Soal Matematika pada Materi Himpunan Kelas VII SMP/MTs. Jurnal Cendekia: Jurnal Pendidikan Matematika, 5(1), 484-500. https://doi.org/10.31004/cendekia.v5i1.503

Azhar, W. S., \& Senjayawati, E. (2021). Analisis Kesalahan Siswa SMK dalam Menyelesaikan Soal Materi Geometri Ruang. JPM: Jurnal Pendidikan Matematika, 4(1), 185-192. https://doi.org/10.2246o/jpmi.v4i1.p\%25p

Dewi, S. P., \& Kartini, K. (2021). Analisis Kesalahan Siswa dalam Menyelesaikan Soal Sistem Persamaan Linear Tiga Variabel Berdasarkan Prosedur Kesalahan Newman. Jurnal Cendekia: Jurnal Pendidikan Matematika, 5(1), 632-642. https://doi.org/10.31004/cendekia.v5i1.508

Dirgantoro, K. P. S. (2018). Kompetensi Guru Matematika dalam Mengembangkan Kompetensi Matematis Siswa. Scholaria: Jurnal Pendidikan dan Kebudayaan, 8(2), 157-166. https://doi.org/10.24246/j.js.2018.v8.i2.p157-166

Fajar, A. P., Kodirun, Suhar, \& Arapu, L. (2018). Analisis Kemampuan Pemahaman Konsep Matematis Siswa Kelas VIII SMP Negeri 1 Kendari. Jurnal Pendidikan Matematika, 9(2), 229-239. https://doi.org/10.36709/jpm.v9i2.5872

Farida, N. (2015). Analisis Kesalahan Siswa SMP Kelas VIII dalam Menyelesaikan Masalah Soal Cerita Matematika. Jurnal Aksioma, 4(2), 42-52. https://doi.org/10.24127/ajpm.v4i2.306

Fitra, R. (2020). Analisis Kesalahan Mahasiswa dalam Menyelesaikan Masalah Pemodelan Matematika Sederhana. Jurnal Ilmiah Pendidikan Indonesia, 8(1), 1-7. https://www.ejournal.stkipbbm.ac.id/index.php/mtk/article/view/590

Haryadi, R., \& Nurmaningsih. (2019). Analisis Kesalahan Mahasiswa dalam Menyelesaikan Soal Persamaan Garis Lurus. Jurnal Elemen, 5(1), 1-11. https://e- 
Al- Ishlah: Jurnal Pendidikan, June 2021, 13 (1), Pages 741-748

Suharti, Fitriani Nur, Bahrul Alim

journal.hamzanwadi.ac.id/index.php/jel/article/view/703

Hendriana, H., Rohaeti, E. E., \& Sumarmo, U. (2017). Hard Skills dan Soft Skills Matematika Siswa. Refika Aditama.

Hidayat, D. W., \& Pujiastuti, H. (2019). Analisis Kesalahan Siswa dalam Menyelesaikan Masalah Matematis pada Materi Himpunan. Jurnal Analisa, 5(1), 59-67. https://doi.org/10.15575/ja.v5i1.4120

Ichsan, M. (2016). Psikologi Pendidikan dan Ilmu Mengajar. Jurnal Edukasi, 2(1), 60-76. https://doi.org/10.22373/je.v2i1.691

Komarudin. (2016). Analisis Kesalahan Siswa dalam Pemecahan Masalah Matematika pada Materi Peluang Berdasarkan High Order Thinking dan Pemberian Scaffolding. Jurnal Darussalam: Jurnal Pendidikan, Komunikasi, dan Pemikiran Hukum Islam, 8(1), 202-217. https://core.ac.uk/download/pdf/230913581.pdf

Lenchner, G. (1983). Creative Problem Solving in School Mathematics. Houghton Mifflin College Div.

Moleong, L. J. (2018). Metode Penelitian Kualitatif. PT Remaja Rosdakarya.

Nengrum, T. A., Solong, N. P., \& Iman, M. N. (2021). Kelebihan dan Kekurangan Pembelajaran Luring dan Daring dalam Pencapaian Kompetensi Dasar Kurikulum Bahasa Arab di Madrasah Ibtidaiyah 2 Kabupaten Gorontalo. Jurnal Pendidikan, 3O(1), 1-12. https://doi.org/10.32585/jp.v30i1.1190

Nurkholis. (2013). Pendidikan dalam Upaya Memajukan Teknologi. Jurnal Kependidikan, 1(1), 2444.

http://ejournal.iainpurwokerto.ac.id/index.php/jurnalkependidikan/article/download/530 /473/

Ramadhan, A., Anwar, S., \& Falak, A. F. (2021). Analisis Kesalahan Siswa dalam Menyelesaikan Soal Pemecahan Masalah Matematik Siswa SMK Kelas X Materi Sistem Persamaan Linear Dua Variabel. JPMI-Jurnal Pembelajaran Matematika Inovatif, 4(2), 323-330. https://doi.org/10.22460/jpmi.v4i2.323-330

Siswandi, E., Sujadi, I., \& Riyadi. (2016). Analisis Kesalahan Siswa dalam Menyelesaikan Masalah Matematika Kontekstual pada Materi Segiempat Berdasarkan Analisis Newman Ditinjau dari Perbedaan Gender (Studi Kasus pada Siswa Kelas VII SMPN 20 Surakarta). Jurnal Elektronik Pembelajaran Matematika, 4(7), 633-643. https://jurnal.fkip.uns.ac.id/index.php/s2math/article/view/9169

Sitorus, Y. I., \& Sutirna. (2021). Analisis Kesalahan Siswa SMA dalam Pemecahan Masalah Matematis pada Materi Program Linier. Maju: Jurnal Ilmiah Pendidikan Indonesia, 8(1), 282-290. https://ejournal.stkipbbm.ac.id/index.php/mtk/article/view/627

Sulistyaningsih, A., \& Rakhmawati, E. (2017). Analisis Kesalahan Siswa Menurut Kastolan dalam Pemecahan Masalah Matematika. Seminar Matematika dan Pendidikan Matematika UNY, 123-130.

http://seminar.uny.ac.id/semnasmatematika/sites/seminar.uny.ac.id.semnasmatematika/f iles/full/M-19.pdf

Wati, M. K., \& Sujadi, A. A. (2017). Analisis Kesalahan dalam Menyelesaikan Masalah Matematika dengan Menggunakan Langkah Polya Siswa Kelas VII SMP. Jurnal Prisma, 6(1), 9-16. https://doi.org/10.35194/jp.v6i1.24

Wibowo, I. S., \& Farnisa, R. (2018). Hubungan Peran Guru dalam Proses Pembelajaran terhadap Prestasi Belajar Siswa. Jurnal Gentala Pendidikan Dasar, 3(2), 181-202. https://doi.org/10.22437/gentala.v3i2.6758

Widodo, S. A. (2013). Analisis Kesalahan dalam Pemecahan Masalah Divergensi Tipe Membuktikan pada Mahasiswa Matematika. Jurnal Pendidikan dan Pengajaran, 46(2), 106-113. https://www.researchgate.net/publication/311645939_ANALISIS_KESALAHAN_DALAM PEMECAHAN_MASALAH_DIVERGENSI_TIPE_MEMBUKTIKAN_PADA_MAHASISW A_MATEMATIKA

Widyawati, A., Afifah, D. S. N., \& Resbiantoro, G. (2018). Analisis Kesalahan Siswa dalam Memecahkan Masalah Lingkaran Berdasarkan Taksonomi Solo pada Kelas VIII. Jurnal Pendidikan Matematika dan Sains, 6(1), 1-9. https://journal.uny.ac.id/index.php/jpms/article/view/15087 